\title{
Biology of Triatoma klugi Carcavallo, Jurberg, Lent \& Galvão 2001 (Heteroptera: Reduviidae) under Laboratory Conditions: Effects of Distinct Blood Sources and Susceptibility to Trypanosoma cruzi and Trypanosoma rangeli
}

\author{
Priscilla Emmanuelle-Machado, Leonardo B Koerich, Daiene De Boni Joukoski, \\ Carlos J Carvalho-Pinto ${ }^{+}$, Edmundo C Grisard, Mário Steindel
}

Departamento de Microbiologia e Parasitologia, Universidade Federal de Santa Catarina, Caixa Postal 476, 88040-900

Florianópolis, SC, Brasil

The life cycle of Triatoma klugi Carcavallo, Jurberg, Lent \& Galvão 2001 was compared under laboratory conditions using two groups of the F1 generation obtained from field-collected bugs. Among the 100 nymphs weekly fed on mice (Group A) or chicken (Group B), 77\% of Group A and 67\% of Group B reached the adult stage, and the mean time from the first nymphal stage to adult was $190.08 \pm 28.31$ days and $221.23 \pm 40.50$, respectively. The average span in days for each stage per group and the number of blood meals required for each stage were also evaluated. The overall mortality rate was $23 \%$ and $33 \%$ for Groups A and B, respectively. The mean number of eggs laid per month in a three-month period was of 56.20, 51.70 and 73.20 for Group A, and 64.50, 53.50 and 38.71 for Group B. Despite the blood source, comparative analysis revealed no statistically significant differences in the life cycle of $\mathrm{T}$. klugi under laboratory conditions. Infection rates over $60 \%$ were observed for both Trypanosoma cruzi strains tested. Even revealing high infection rates of the hemolymph by T. rangeli strains, T. klugi revealed no salivary gland infections and was not able to transmit the parasite.

Key words: Triatoma klugi - life cycle - triatomine - trypanosomes

The genus Triatoma is wide spread in Latin American countries, comprising sylvatic, peridomestic and domestic triatomines and representing almost $50 \%$ of all triatomine species. Some species of this genus such as Triatoma infestans, T. dimidiata, T. brasiliensis, $T$. pseudomaculata, T. sordida, T. maculata, T. barberi and T. phyllosoma are of major importance in the peridomestic and domestic transmission of Trypanosoma cruzi, the causative agent of Chagas disease (Dias 1987, Dias \& Schofield 1999). Moreover, some species of the genus Triatoma may also act as $T$. rangeli vectors in some Central and South American countries (D'Alessandro \& Saravia 1992, 1999).

Triatomine development may be influenced by environmental conditions as well as the availability and appropriateness of blood sources (Schofield 1985). Although triatomines can fed in a variety of hosts (mammalian, avian, reptilian and insects) in natural ecotopes, several studies carried out under laboratory conditions demonstrated that insects fed in mammals presented a shorter life cycle when compared with those fed on other blood sources (Juarez 1970, Guarneri et al. 2000, Lorosa et al. 2000).

T. klugi is a new triatomine species originally found in rock cracks without or with scarce vegetation in the State

This work was supported by ECLAT and CNPq.

${ }^{+}$Corresponding author. Fax: +55-48-331.9258. E-mail: ccb1ccp@ccb.ufsc.br

Received 11 October 2001

Accepted 7 January 2002 of Rio Grande do Sul, Southern Brazil (Carcavallo et al. 2001). Morphologically related to T. oliveirai this new species was included into the "oliveirai complex", which also comprises T. matogrossensis Leite \& Barbosa 1953, T. oliveirai (Neiva, Pinto \& Lent) 1939, T. williami Galvão, Souza \& Lima 1965, T. guazu Lent \& Wygodzinsky 1979 and T. jurbergi Carcavallo, Galvão \& Lent 1998 (Carcavallo et al. 2001). Preliminary data about $T$. klugi blood sources derived from precipitin tests revealed the presence of bird and rodent blood, as well as coackroaches hemolymph (Carvalho-Pinto et al. 2000). In the present work, biological aspects of T. klugi life cycle were evaluated under laboratory conditions using two different blood sources.

\section{MATERIALS AND METHODS}

Triatomines used in this study were the $\mathrm{F} 1$ generation obtained from adults and nymphs collected at Nova Petrópolis, State of Rio Grande do Sul, Brazil (Carcavallo et al. 2001). The original colony was established in our laboratory in 1999 and is maintained under $28 \pm 1^{\circ} \mathrm{C}$ of temperature and $75 \pm 5 \%$ of relative humidity (r.h.) and fed weekly on Swiss mice.

In order to determine the incubation period and hatching time, eggs from field-collected bugs were grouped daily by date of oviposition forming two cohorts of 100 eggs named as Group A and Group B. After eclosion, first-instar nymphs were individually disposed into plastic vials ( $3.5 \mathrm{~cm}$ diameter $\mathrm{x} 6 \mathrm{~cm}$ height) covered with nylon mesh. Ten days after eclosion, nymphs were fed for 1 $\mathrm{h}$ on adult mice (Mus musculus) for Group A or on chicken (Gallus gallus) for Group B. Insects were weekly fed for 1 $h$ on the same blood sources until the end of the experiment. During the whole study insects were maintained 
under controlled conditions as described for the colony, and had their mortality and ecdysis checked daily.

Among the triatomines who reached the adult stage, 10 couples of each group were separated in plastic vials. These insects were maintained as described before in order to determine (a) the period comprised between mating and oviposition, (b) the number of eggs laid per female and (c) adult survivorship within a 3 months period.

The obtained data were compared by non-parametric test (Mann-Whitney), considering significant differences when $\mathrm{p}<0.05$.

Aiming the determination of the amount of blood ingested by insects in each instar, a group of 10 insects of each instar were individually weighed before and immediately after feeding on mice. In order to evaluate $T$. klugi susceptibility to T. cruzi and T. rangeli, groups of 30 nymphs of T. klugi on 4th and 5th instars were fed for $2 \mathrm{~h}$ on anesthetized mice in the peak of blood parasitemia, infected with T. cruzi (SC-28 and Y strains) and T. rangeli (SC-58 and Choachi strains). Engorged insects (28 for Y, 27 for SC-28, 30 for Choachi and 26 for SC-58 strains) were separated and maintained under controlled conditions of temperature and r.h., monthly fed on normal mice and daily checked for mortality. Monthly, fresh preparations of feces (obtained by abdominal compression) or hemolymph (collected by excising a leg) from each insect were searched for T. cruzi and T. rangeli infection. All surviving insects infected by $T$. rangeli had their intestine and salivary glands individually dissected and searched for the presence of parasites 80 days after the infective blood meal.

In order to evaluate infectivity of intestine and hemolymph-derived parasites, two groups of 5 Swiss mice were inoculated by intraperitoneal or oral routes with positive feces or hemolymph from triatomines experimentally infected with $T$. rangeli. Mice were daily searched for the presence of parasite by fresh blood examinations and bled on day 15th post inoculation for hemoculture in LIT medium.

\section{RESULTS}

The hatching rate of the F1 generation was $100 \%$ for both groups with a mean incubation period of $19.5 \pm 1.45$ days (range 18-27 days) for Group A and 22.0 days for Group B, which was the same observed for field-collected bugs. For Group A, 77 nymphs completed the development to adult stage (35 females and 42 males) and for Group B, 67 nymphs reached the adult stage ( 31 females and 36 males).

The mean development time from 1 st instar nymph to adult was of $190.08 \pm 28.31$ days for Group A and 221.23 \pm 40.50 days for Group B and the number of blood meals per stage varied from 1 to 19 for group A and from 1 to 23 for Group B. The accumulate death rate was of $23 \%$ and $33 \%$ for Groups A and B, respectively (Tables I, II). Comparison of the spent time for the entire life cycle did not show statistically significant differences between the two groups.

The mean time from mating to start of oviposition in days was of 11.2 (range 7-18) and 13.5 (range 10-17) for females fed on chicken and mice, respectively. The mean number of eggs laid per female fed on mice was of $56.20 \pm$ 31.41 at the first month, $51.70 \pm 20.06$ at the second month and $73.20 \pm 33.62$ at the third month. On the group fed on chicken, the mean number of eggs laid per female was of $64.50 \pm 21.56$ at the first month, $53.50 \pm 19.78$ at the second month and $38.71 \pm 19.22$ at the third month. No significant differences were observed in the number of eggs laid per female after two months of breeding. However, statistically significant differences $(p=0.02)$ were observed on the egg production on the third month between females fed on mice and chicken (Figure). The survivorship rate of adults fed on chicken and mice in a three months period was of $70 \%$ and $100 \%$, respectively.

The amount of blood ingested by insects in each instar as well as by adults fed on mice is shown in Table III. The weight of ingested blood in milligrams varied from 2.1 to 5.0 times the initial body weight for nymphs and was of 1.1 times for adults.

TABLE I

Duration of Triatoma klugi Carcavallo, Jurberg, Lent \& Galvão 2001 biological cycle fed on mice (Group A)

\begin{tabular}{|c|c|c|c|c|}
\hline Stage & Number & $\begin{array}{l}\text { Duration in days } \\
\quad \text { (min-max) }\end{array}$ & $\begin{array}{l}\text { Number of blood } \\
\text { meals }{ }^{a} \text { (min-max) }\end{array}$ & $\begin{array}{c}\text { Mortality } \\
\%\end{array}$ \\
\hline Eggs-NI & 100 & $\begin{array}{l}19.50 \pm 1.45 \\
(18-27)\end{array}$ & - & 0 \\
\hline NI-NII & 92 & $\begin{array}{c}20.91 \pm 2.88 \\
(18-28)\end{array}$ & $\begin{array}{c}1.28 \pm 0.45 \\
(1-2)\end{array}$ & 8 \\
\hline NII-NIII & 88 & $\begin{array}{c}23.94 \pm 6.27 \\
(17-64)\end{array}$ & $\begin{array}{l}3.15 \pm 1.0 \\
(2-10)\end{array}$ & 4 \\
\hline NIII-NIV & 80 & $\begin{array}{c}26.72 \pm 6.84 \\
(08-48)\end{array}$ & $\begin{array}{c}3.47 \pm 0.99 \\
(1-6)\end{array}$ & 8 \\
\hline NIV-NV & 77 & $\begin{array}{c}36.17 \pm 12.52 \\
(23-109)\end{array}$ & $\begin{array}{c}4.78 \pm 1.77 \\
(3-15)\end{array}$ & 3 \\
\hline NV-AD & 77 & $\begin{array}{c}62.39 \pm 23.43 \\
(36-134)\end{array}$ & $\begin{array}{l}8.52 \pm 3.35 \\
(5-19)\end{array}$ & 0 \\
\hline Total & 77 & $\begin{array}{l}190.08 \pm 28.31 \\
(120-410)\end{array}$ & - & 23 \\
\hline
\end{tabular}

$a$ : Mean $\pm \mathrm{SD}$; NI-NV: first to fifth instar nymphs; AD: adults 
TABLE II

Duration of Triatoma klugi biological cycle fed on chicken (Group B)

\begin{tabular}{|c|c|c|c|c|}
\hline Stage & Number & $\begin{array}{l}\text { Duration in days } \\
\quad \text { (min-max) }\end{array}$ & $\begin{array}{l}\text { Number of blood } \\
\text { meals }{ }^{a} \text { (min-max) }\end{array}$ & $\begin{array}{c}\text { Mortality } \\
\%\end{array}$ \\
\hline Eggs-NI & 100 & $\begin{array}{l}22.0 \pm 0.0 \\
(22)\end{array}$ & - & 0 \\
\hline NI-NII & 77 & $\begin{array}{c}30.71 \pm 9.27 \\
(21-59)\end{array}$ & $\begin{array}{c}4.00 \pm 1.27 \\
(3-8)\end{array}$ & 23 \\
\hline NII-NIII & 77 & $\begin{array}{c}29.95 \pm 7.60 \\
(7-47)\end{array}$ & $\begin{array}{c}3.77 \pm 1.05 \\
(1-6)\end{array}$ & 0 \\
\hline NIII-NIV & 72 & $\begin{array}{c}39.35 \pm 8.0 \\
(19-63)\end{array}$ & $\begin{array}{c}5.11 \pm 1.16 \\
(2-8)\end{array}$ & 5 \\
\hline NIV-NV & 72 & $\begin{array}{l}45.72 \pm 20.08 \\
(22-114)\end{array}$ & $\begin{array}{l}5.92 \pm 2.88 \\
(3-16)\end{array}$ & 0 \\
\hline NV-AD & 67 & $\begin{array}{l}58.04 \pm 20.92 \\
(26-160)\end{array}$ & $\begin{array}{c}7.93 \pm 3.07 \\
(3-23)\end{array}$ & 5 \\
\hline Total & 67 & $\begin{array}{c}221.23 \pm 40.50 \\
(117-465)\end{array}$ & - & 33 \\
\hline
\end{tabular}

$a$ : Mean $\pm \mathrm{SD}$; NI-NV: first to fifth instar nymphs; AD: adults

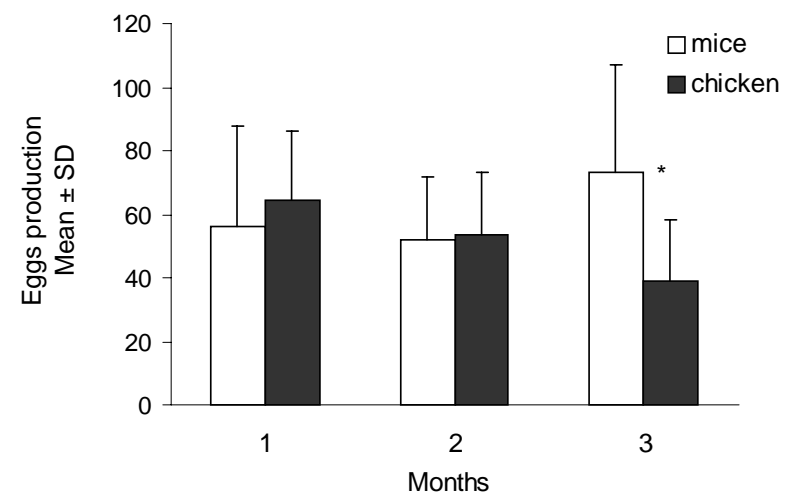

Mean number of eggs produced per female of Triatoma klugi Carcavallo, Jurberg, Lent \& Galvão 2001 fed on mice and chicken during a three months period. Vertical bars indicate standard deviation of the mean; *statistically significant difference (MannWhitney, $\mathrm{p}=0.02$ )

Under our experimental conditions, i.e. controlled temperature and humidity, and absence of competition, the mean number of T. klugi blood meals ranged from 1.28 to 8.52 during distinct nymphal stages, and the amount of blood ingested by nymphs and adults ranged from 1.1 to 5 times the original body weight.
The infection rates of $T$. klugi fed on mice infected with $T$. cruzi and T. rangeli strains are shown in Table IV. Insects infected with $T$. cruzi strains presented both epimastigotes and metacyclic trypomastigotes on their feces after 30 days of infection. The accumulated mortality rate varied from $26.2 \%$ to $30 \%$. T. rangeli hemolymph infection rate increases during the experiment (Table IV). The overall accumulate infection rate was of $81.8 \%$ and $83.3 \%$ for strains SC-58 and Choachi, respectively. Besides the $T$. rangeli strain used a high parasite growth in the insects hemolymph was observed. The accumulate mortality rate was of $63.3 \%$ and $60 \%$ for strains SC-58 and Choachi, respectively. Despite the heavy hemolymph infection, none of these insects presented flagellates in their salivary glands. All the mice inoculated with infected feces and/or hemolymph by oral or intraperitoneal route were negative for parasites in both fresh blood examinations and hemoculture.

\section{DISCUSSION}

The development cycle of triatomines is quite distinct among different species and may be affected by environmental conditions such as the availability and the appropriateness of blood sources (Szumlewicz 1975, Schofield 1985). In the present work, using controlled rearing conditions and absence of competition between individuals,

TABLE III

Amount of blood ingested (mg) by Triatoma klugi in each development stage mice ${ }^{a}$

\begin{tabular}{lccr}
\hline Stage & Initial weight & Final weight & Total ingested \\
\hline NI & $1.46 \pm 0.14$ & $4.59 \pm 2.93$ & $3.13 \pm 2.79$ \\
NII & $3.95 \pm 0.46$ & $23.84 \pm 4.89$ & $19.89 \pm 4.43$ \\
NIII & $11.03 \pm 3.13$ & $61.59 \pm 12.66$ & $50.56 \pm 9.53$ \\
NIV & $32.78 \pm 7.41$ & $146.45 \pm 44.29$ & $113.67 \pm 36.88$ \\
NV & $85.30 \pm 19.64$ & $305.99 \pm 58.46$ & $220.69 \pm 38.82$ \\
AD & $158.67 \pm 28.72$ & $334.00 \pm 116.27$ & $175.33 \pm 87.55$ \\
\hline
\end{tabular}

$a$ : Mean \pm SD of ten insects for each development stage; NI-NV: first to fifth instar nynphs; AD: adults 
TABLE IV

Infection rate of Triatoma klugi by Trypanosoma cruzi (feces) and by T. rangeli (hemolymph) after different periods of the infective blood meal on Swiss mice ${ }^{a}$

\begin{tabular}{lcccc}
\hline $\begin{array}{l}\text { Days after } \\
\text { infection }\end{array}$ & SC-28 & T. cruzi strains & \multicolumn{2}{c}{ T. rangeli strains } \\
\hline 30 & 66.6 & Y & SC-58 & 50.9 \\
& $(12)$ & $(15)$ & 39.2 & $(6.7)$ \\
60 & 70.0 & 56.1 & 54.2 & 75.4 \\
& $(19)$ & $(25.2)$ & $(30)$ & $(35)$ \\
80 & 71.2 & 62.0 & 81.8 & 83.3 \\
& $(26.2)$ & $(30)$ & $(63.3)$ & $(60)$ \\
\hline
\end{tabular}

$a$ : results represent the mean of two independent experiments $(\mathrm{n}=30)$. Numbers in parenthesis show cumulative mortality rates.

the entire development cycle of T. klugi was completed in $190.08 \pm 28.31$ days (range 120-410 days) for insects fed on mice and in $221.23 \pm 40.50$ days (range 117-465 days) for insects fed on chicken. Previous observations from $T$. $k$ lugi collected in the field showed the presence of both rodent and bird blood by precipitin tests (Carvalho-Pinto et al. 2000). In this work, insects fed on mice revealed a shorter time to reach the adult stage, but no significant differences were revealed between the experimental groups.

Triatomine mortality and/or development are influenced by several factors such as spontaneous starvation or inappropriate blood-meal intake, temperature, luminosity and humidity (Rocha et al. 1994, Luz et al. 1999). Development of $T$. infestans and $T$. sordida fed on pigeons or in mice showed a higher mortality rate for 1 st instar nymphs (Guarneri et al. 2000).

Despite the high mortality rate observed among first instar nymphs of T. klugi from Group B in this study, which may be attributed in part to the difficulty or incapability of the insects to feed on chicken under experimental conditions, the accumulate mortality rate observed for Group A and Group B was not significantly different (Chisquare, $\mathrm{p}=0.2$ ).

It is well established in the literature that food sources and environmental conditions may have influence on triatomine development (Juarez 1970, Gomes et al. 1990, Guarneri et al. 2000).

Using mice as blood source, distinct authors studied the biological cycle of $T$. sordida and $T$. vitticeps under experimental conditions $\left(25-28^{\circ} \mathrm{C}\right.$ and $60-80 \%$ of r.h.), revealing a mean development time around of 170 and 270 days, respectively (Souza et al. 1978, Gonçalves et al. 1988).

Comparing the life cycle of $T$. brasiliensis, $T$. infestans, T. pseudomaculata and T. sordida fed on mice and pigeons and maintained at $28 \pm 1^{\circ} \mathrm{C}$ and $60 \pm 5 \%$ of r.h., the authors observed a mean development time of 119.7, 161.9, 232.6 and 119.7 days for insects fed on mice and 282, 247, 335.4 and 252.7 days for insects fed on pigeons, respectively (Guarneri et al. 2000).

Using chicken as blood source, the influence of the temperature on $T$. jurbergi life cycle, a T. klugi-related species, was evaluated. A mean development time of 601.9 days was observed for insects maintained at $25^{\circ} \mathrm{C}$ and
186.1 days for insects maintained at $30^{\circ} \mathrm{C}$ (Gomes \& da Silva 2000).

In our experimental conditions, T. klugi presented a mean development time of $190.08 \pm 28.31$ days and 221.23 \pm 40.50 days for insects fed on mice and chicken, respectively. Based on these results, under standard laboratory conditions the production of one or two generations per year can be expected. However, field observations carried out in Nova Petrópolis (RS, Brazil) revealed that temperature might reach values below $0^{\circ} \mathrm{C}$ during winter (May to August) and over $30^{\circ} \mathrm{C}$ during summer (October to March). The temperature variation as well as the absence of a constant blood source in the field must be considered for prediction of the number of T. klugi generations/ year under natural conditions (Carvalho-Pinto et al. 2000).

As observed for the development time, egg hatching rates among triatomine species are also variable and may be affected by inbreeding rate as well as by environmental conditions such as temperature and relative humidity. Despite this consideration, an overall hatching rate over $80 \%$ is reported for distinct triatomine species in different studies (Szumlewicz 1975, Canale et al. 1999).

Comparative studies of T. brasiliensis, T. infestans, $T$. pseudomaculata and $T$. sordida hatching under experimental conditions using a single blood source revealed rates from $64.3 \%$ to $95.8 \%$ among the four different species (Guarneri et al. 2000). Similar studies carried out with T. jurbergi at two distinct temperatures revealed hatching rates of $39.9 \%$ at $25^{\circ} \mathrm{C}$ and $69.4 \%$ at $30^{\circ} \mathrm{C}$, confirming the influence of temperature in both feeding and hatching processes (Gomes \& da Silva 2000). Under our experimental conditions, i.e. controlled temperature and humidity as well as constant blood meals, T. klugi revealed a hatching rate of $100 \%$. This hatching success can be attributed to (i) the use of a F1 generation (low or absent inbreeding rate), (ii) the constant offer of blood meals under experimental conditions or (iii) the influence of controlled temperature and humidity.

The usual amount of blood ingested by triatomines nymphs and adults may range from 6 to 12 times the original body weight, having a direct influence on the female fecundity and the reproductive success of the species as well (Kollien \& Schaub 2000). Moreover, the blood meal source also have influence on triatomine reproductive 
success, which was demonstrated when $T$. brasiliensis and $T$. sordida fed on mice presented a higher egg production when compared with insects fed on pigeons (Guarneri et al. 2000).

The efficacy of $T$. cruzi transmission to mammalian hosts is dependent on several factors such as the insect susceptibility to the parasite strain, the mean time between feeding and defecation of contaminated triatomine feces over the host skin as well as the number of blood meals taken in each life stage, allowing predictions of the triatomine vectorial capacity (Galvão et al. 1995).

Preliminary data on T. klugi susceptibility to distinct T. cruzi strains showed similar infection patterns as observed for T. infestans (Joukoski et al. 2000). Although $T$. $k l u g i$ is originally found only in sylvatic environment and on natural T. cruzi infection has been found up to now, our findings suggest that this species should be considered a potential T. cruzi vector in the sylvatic environment.

Intestinal infections by $T$. rangeli have been observed in several species of the genus Triatoma in distinct Latin American countries. Moreover, experimental studies carried out with $T$. rangeli strains revealed salivary gland infections of some species such as $T$. dimidiata, $T$. patagonica, T. protracta, T. vitticeps and T. infestans, suggesting that these triatomine species may act as vectors of the parasite (D'Alessandro \& Saravia 1992, 1999). In this study, T. klugi fed on experimentally infected mice revealed high hemolymph infection by both $T$. rangeli strains. However, no insects showed salivary gland infection, suggesting that this species is not able to transmit the parasite under natural conditions.

Swiss mice inoculated with $T$. rangeli derived from $T$. klugi feces and hemolymph showed no infection, confirming that these $T$. rangeli forms are not infective to the vertebrate hosts (D’Alessandro \& Saravia 1992).

\section{ACKNOWLEDGMENTS}

To Alessandra A Guarneri for her critical review of the manuscript.

\section{REFERENCES}

Canale DM, Jurberg J, Carcavallo RU, Galvão C, Girón IG, Segura CAM, Rocha DS, Martínez A 1999. Bionomics of some species. In RU Carcavallo, IG Girón, J Jurberg, H Lent (eds), Atlas of Chagas Disease Vectors in the Americas, Fiocruz, Rio de Janeiro, p. 839-890.

Carcavallo RU, Jurberg J, Lent H, Galvão C, Steindel M, Carvalho Pinto CJ 2001. Nova espécie do complexo oliveirai (nova denominação para o complexo matogrossensis) (Hemiptera, Reduviidae, Triatominae) do Estado do Rio Grande do Sul, Brasil. Mem Inst Oswaldo Cruz 95: 333-334.

Carvalho-Pinto CJ, Grisard EC, Loroza ES, Steindel M 2000. Ecological and behavioral aspects of Triatoma klugi, a new triatomine species recently described from Rio Grande do Sul State, Brazil. Mem Inst Oswaldo Cruz 95 (Suppl. II): 336-337.
D’Alessandro A, Saravia NG 1992. Trypanosoma rangeli. In JP Kreier, JR Baker (eds), Parasitic Protozoa, Academic Press, San Diego, p. 1-54.

D'Alessandro A, Saraiva NG 1999. Trypanosoma rangeli. In HM Gilles, Protozoal Diseases, Arnold Press Inc., London, p. 398-412.

Dias JCP 1987. Control of Chaga's Diasease in Brazil. Parasitol Today 3: 336-341.

Dias JCP, Schofield CJ 1999. The evolution of Chagas disease (American trypanosomiasis) control after 90 years since Carlos Chagas discovery. Mem Inst Oswaldo Cruz 94 (Suppl. I): 103-121.

Galvão C, Jurberg J, Cunha V, de Mello RP 1995. Biologia do Triatoma nitida Usinger, 1939 em laboratório (Hemiptera: Reduviidae). Mem Inst Oswaldo Cruz 90: 657-663.

Gomes AB, da Silva IG 2000. Influência da temperatura na biologia de triatomíneos. XXI. Triatoma jurbergi Carcavallo, Galvão \& Lent, 1998 (Hemiptera, Reduviidae). Rev Patol Trop 29: 85-93.

Gomes JE, Azambuja P, Garcia ES 1990. Comparative studies on the growth and reprodutive performances of Rhodnius prolixus reared on different blood sources. Mem Inst Oswaldo Cruz 85: 299-304.

Gonçalves TCM, Victório VMN, Jurberg J, Cunha V 1988. Biologia do Triatoma vitticeps (Stal, 1859) em condições de laboratório (Hemiptera: Reduviidae, Triatominae). I. Ciclo Evolutivo. Mem Inst Oswaldo Cruz 83: 519-523.

Guarneri AA, Pereira MH, Diotaiuti L 2000. Influence of the blood meal source on the development of Triatoma infestans, Triatoma brasiliensis, Triatoma sordida and Triatoma pseudomaculata (Heteroptera: Reduviidae). J Med Entomol 37: 373-379.

Joukoski DDB, Grisard EC, Steindel M 2000. Evaluation of the vectorial capacity of Triatoma klugi, a new triatomine species. Mem Inst Oswaldo Cruz 95 (Suppl. II): 333

Juarez E 1970. Comportamento do Triatoma infestans sob várias condições de laboratório. Rev Saúde públ 4: 147-166.

Kollien A, Schaub G 2000. Development of Trypanosoma cruzi in triatomine. Parasitol Today 16: 381-387.

Lorosa ES, Jurberg J, Souza ALA, Vinhaes MC, Nunes JM 2000. Hemolinfa de Dyctyoptera na manutenção do ciclo biológico silvestre de Triatoma rubrovaria (Blanchard, 1843) e T. circummaculata (Stal, 1859) Hemiptera, Reduvidae, Triatominae. Entomol Vect 7: 287-296.

Luz C, Fargues J, Grunewald J 1999. Development of Rhodnius prolixus (Hemiptera: Reduviidae) under constant and cyclic conditions of temperature and humidity. Mem Inst Oswaldo Cruz 94: 403-409.

Szumlewicz A 1975. Laboratory colonies of Triatominae, biology and population dynamics. PAHO Scien Publ 318: 6382 .

Rocha da Silva D, Galvão C, Jurberg J 1994. Biologia do Rhodnius pictipes Stal, 1872 em condições de laboratório (Hemiptera: Reduviidae, Triatominae). Mem Inst Oswaldo Cruz 89: 265270.

Schofield CJ 1985. Population dynamics and control of Triatoma infestans. Annales de la Société Belge de Médicine Tropicale 65 (Suppl.): 149-164

Souza JMP, Rodrigues VLCC, Silva EOR 1978. Triatoma sordida - Considerações sobre o tempo de vida das formas adultas e sobre a oviposição das fêmeas. Rev Saúde públ 12: 291-296. 